\title{
OPTIMASI PENURUNAN NILAI BOD, COD DAN TSS LIMBAH CAIR INDUSTRI TAPIOKA MENGGUNAKAN ARANG AKTIF DARI AMPAS KOPI
}

\author{
Irmanto dan Suyata \\ Program Studi Kimia Fakultas Sains dan Teknik Universitas Jenderal Soedirman \\ E-mail: irmpwt@yahoo.com
}

\begin{abstract}
Activated carbon from coffee dregs for TSS, BOD and COD removal of tapioca industrial wastewater has been developed. The research aimed to know the quality of activated carbon from dregs of coffee as adsorbent, consist of total rendemen, water content, ashes content and iodium adsorption; to know about the optimum contact time and optimum $\mathrm{pH}$ from activated carbon on reducing BOD, COD and TSS value from tapioca industrial wastewater and also to know about the decrease percentage of BOD, COD and TSS value using activated carbon from dregs of coffee. Activated carbon from dregs of coffee are activated using $\mathrm{HCl} 0,1 \mathrm{~N}$ and carbonization at $350^{\circ} \mathrm{C}$ in muffle furnace. Then, activated carbon was contacted with the tapioca industrial wastewater and used on decreasing BOD, COD and TSS value from tapioca industrial wastewater with contact time varieties $0,10,30,60,90$ and 120 minutes and at $\mathrm{pH}$ varieties of wastewater 4, 5, 6, 7, 8, 9 and 10. The decreasing of BOD value was measured by Winkler method, decreasing of COD value measured by iodometric method and decreasing of TSS value measured by gravimetric method. The result of the research showed that the activated carbon produced characteristic consist of rendemen 14,55\%; water content 3,4\%; ashes content $1,88 \%$ and iodium adsorption $750,25 \mathrm{mg} / \mathrm{g}$. It is indicated that the activated carbon that is got from dregs of coffee fulfill the criteria required by SNI No. 06-3730-1995. The result of research also showed that the activated carbon from dregs of coffee could be used for reducing the BOD, COD and TSS value in tapioca industrial wastewater at the optimum contact time of 30 minutes and $\mathrm{pH}$ 7. The optimum percentage of activated carbon from dregs of coffee in decreasing BOD value of tapioca industrial wastewater are $33,51 \%$; COD value $78,96 \%$ and TSS value $61,05 \%$.
\end{abstract}

Keywords : activated carbon, tapioca wastewater, BOD, COD

\section{PENDAHULUAN}

Limbah industri tapioka

dihasilkan dalam proses pembuatan tepung tapioka, pada saat pengupasan kulit, pencucian bahan baku dan pada proses pengendapan pati dari airnya. Limbah yang dihasilkan dapat berupa limbah padat, limbah gas dan limbah cair. Limbah padat industri tapioka belum dirasakan dampaknya terhadap lingkungan karena dapat dimanfaatkan sebagai pakan ternak, pupuk dan campuran saus. Limbah gas tapioka dihasilkan dari pengolahan yang tidak tepat pada limbah padat dan cair. Sedangkan limbah cair industri tapioka umumnya berupa suspensi berwarna putih kekuningan dan berbau khas ubi kayu jika masih segar, namun apabila diabaikan, air limbah akan berubah warnanya menjadi abu-abu kehitaman dan berbau busuk. Limbah tapioka mengandung padatan tersuspensi maupun terlarut dan bahan organik yang tinggi yang akan mengalami perubahan fisika, kimia dan hayati sehingga menghasilkan 
zat beracun dan menciptakan media tumbuh kembang kuman (Nurhasan dan Pramudyanto, 1991). Setiap ton ubi kayu yang diolah menjadi tapioka akan menghasilkan limbah cair yang cukup besar yaitu sebesar 14-18 $\mathrm{m}^{3} /$ ton ubi kayu (Direktorat Jenderal Industri Kecil dan Menengah, 2007). Kandungan bahan organik yang tinggi dan padatan tersuspensi yang terkandung dalam limbah cair industri tapioka adalah sebesar 300-400 mg/L untuk BOD, 700$800 \mathrm{mg} / \mathrm{L}$ untuk COD dan 1000-1200 mg/L untuk TSS (Sulistiono, 1989).

Pengendalian limbah secara cermat dan terpadu harus dilakukan oleh pelaku industri agar limbah yang dihasilkan dapat memenuhi baku mutu limbah sehingga volume limbah, konsentrasi dan toksisitas kontaminan limbah dapat diminimalkan. Penanganan limbah industri pangan yang umum digunakan adalah dengan kolam aerobik, koagulasi dan lumpur aktif (Jenie dan Rahayu, 1993). Kelemahan dari metode koagulasi dan lumpur aktif adalah dihasilkannya lumpur kimia (sludge) yang cukup banyak dan diperlukan pengolahan lebih lanjut (Forlink, 2000 dalam Hidayat, 2007). Pemilihan teknologi pengolahan juga harus disesuaikan dengan karakteristik limbah yang akan diolah sehingga dapat dicari solusi terbaik dalam pengolahan limbah yang efisien dan murah (Setiadi, 2007).

Salah satu alternatif pengolahan limbah cair industri tapioka adalah dengan menggunakan arang aktif. Arang aktif dapat digunakan sebagai adsorben karena arang aktif bersifat sangat aktif terhadap partikel yang kontak dengan arang aktif tersebut (Sembiring, 2003). Arang aktif memiliki ruang pori yang sangat banyak dengan ukuran tertentu yang dapat menangkap partikel yang sangat halus dan menjebaknya disana.

Penelitian pendahuluan yang dilakukan Lubis dan Nasution (2002), menjelaskan bahwa penggunaan arang aktif dari ampas kopi sebagai adsorben dapat mengadsorpsi ion besi pada air minum sampai dengan $99,34 \%$ dan arang aktif dari ampas kopi juga mampu mengadsorpsi logam merkuri sampai 99\%. Berdasarkan uraian diatas, arang aktif yang berasal dari ampas kopi diharapkan dapat digunakan sebagai adsorben yang murah dan efisien dalam menurunkan kadar BOD, COD dan TSS dalam air limbah industri tapioka.

Tujuan penelitian ini adalah: Mengetahui kualitas arang aktif dari ampas kopi yang meliputi kualitas rendemen, kadar air, kadar abu dan daya serap terhadap iodium, Menentukan waktu kontak optimum dan $\mathrm{pH}$ optimum arang aktif ampas kopi dalam penurunan nilai BOD, COD dan TSS limbah cair industri tapioka, dan Menentukan persentase penurunan nilai BOD, COD dan TSS limbah cair industri tapioka menggunakan arang aktif ampas kopi.

\section{METODE PENELITIAN \\ Bahan dan Alat}

Bahan yang digunakan adalah limbah cair industri tapioka, ampas kopi jenis kopi robusta, larutan $\mathrm{HCl}, \mathrm{MnSO}_{4}$, $\mathrm{KOH}, \mathrm{KI}, \mathrm{NaN}_{3}, \mathrm{Na}_{2} \mathrm{~S}_{2} \mathrm{O}_{3}, \mathrm{FeCl}_{3}, \mathrm{CaCl}_{2}$, $\mathrm{MgSO}_{4}, \quad \mathrm{H}_{2} \mathrm{SO}_{4}, \quad \mathrm{KMnO}_{4}, \quad \mathrm{~K}_{2} \mathrm{Cr}_{2} \mathrm{O}_{7}$, $\mathrm{H}_{2} \mathrm{SO}_{4}$ pekat, $\mathrm{NaOH}$, buffer fosfat, indikator amilum dan akuades.

Alat-alat yang digunakan adalah alat-alat gelas laboratorium, muffle furnace, desikator, oven, ayakan mekanis 100 mesh, cawan porselin, kertas Whatman nomor 40, kertas saring, neraca analitik, botol Winkler, pH-meter, penangas air, buret dan statif.

\section{Prosedur Penelitian \\ Pembuatan arang aktif}

Ampas kopi dikeringkan dengan dijemur di bawah sinar matahari, setelah kering ampas kopi direndam dalam larutan pengaktif $\mathrm{HCl} 0,1 \mathrm{M}$ selama 48 jam dan ditiriskan, kemudian dicuci dengan aquades sampai netral. Ampas 
kopi yang sudah diaktivasi, dioven untuk mengurangi kandungan airnya terlebih dahulu, dimasukkan ke dalam muffle furnace pada suhu $350^{\circ} \mathrm{C}$ selama 3,5 jam. Setelah proses pengarangan selesai, ampas kopi dibiarkan dingin dan disimpan dalam desikator.

\section{Karakterisasi arang aktif (SII 0258-89) Rendemen}

Rendemen arang aktif dihitung dengan cara membandingkan antara berat bahan baku yang diarangkan dengan berat arang aktif setelah karbonisasi.

Rendemen $(\%)=\frac{b}{a} \times 100 \%$

dimana :

$\mathrm{a}=$ berat bahan baku yang diarangkan $(\mathrm{g})$

$\mathrm{b}=$ berat arang yang dihasilkan $(\mathrm{g})$

\section{Kadar air}

Arang aktif ditimbang sebanyak 2 gram dimasukkan ke dalam cawan porselin yang sebelumnya telah ditimbang dan diketahui beratnya. Cawan beserta arang aktif kemudian dimasukkan ke dalam oven yang diatur suhunya pada $105^{\circ} \mathrm{C}$ selama 3 jam, kemudian didinginkan dalam desikator dan ditimbang massanya.

Kadar air $=\frac{(a-b)}{a} \times 100 \%$

dimana :

$\mathrm{a}=$ berat arang awal (g)

$\mathrm{b}=$ berat contoh setelah dikeringkan $(\mathrm{g})$

\section{Kadar abu}

Arang aktif ditimbang sebanyak 2 gram dimasukkan ke dalam cawan porselin yang telah diketahui beratnya, kemudian contoh dipijarkan dalam muffle furnace pada suhu $600^{\circ} \mathrm{C}$ selama 4 jam atau sampai semua contoh menjadi abu. Cawan kemudian didinginkan dalam desikator dan ditimbang.

Kadar abu $=\frac{a}{b} \times 100 \%$ dimana :

$\mathrm{a}=$ berat $\mathrm{abu}(\mathrm{g})$

$\mathrm{b}=$ berat arang kering pada saat awal $(\mathrm{g})$

\section{Daya serap terhadap iodium}

Arang aktif ditimbang dengan teliti sebanyak 0,5 gram dan dipindahkan ke dalam tempat berwarna gelap dan tertutup, dimasukkan $50 \mathrm{~mL}$ larutan iodium $0,1 \mathrm{~N}$ kemudian dikocok selama 15 menit lalu disaring. Filtrat dipipet sebanyak $10 \mathrm{~mL}$ ke dalam erlenmeyer kemudian dititrasi dengan larutan natrium tiosulfat $0,1 \mathrm{~N}$. Jika warna kuning larutan hampir hilang, ditambahkan indikator amilum. Titrasi kemudian dilanjutkan sampai mendapatkan titik akhir (warna biru tepat hilang).

Daya serap iod $(\mathrm{mg} / \mathrm{g})=\frac{\left[10-\frac{(N \times V)}{0,1}\right]}{s}$

$\times 12,69 \times 5$

dimana :

$\mathrm{V}=$ larutan natrium tiosulfat yang diperlukan $(\mathrm{mL})$

$\mathrm{N}=$ normalitas larutan natrium tiosulfat

$\mathrm{s}=$ berat arang $(\mathrm{g})$

$12,69=$ jumlah iod yang sesuai dengan $1 \mathrm{~mL}$ larutan natrium tiosulfat $0,1 \mathrm{~N}$.

Penentuan nilai BOD, COD dan TSS dalam air limbah industri tapioka sebelum diolah (treatment) dengan arang aktif

a. Masing-masing parameter dianalisis sesuai dengan metode analisis.

b. Pengukuran dilakukan secara duplo.

\section{Penentuan waktu kontak optimum}

Air limbah industri tapioka diambil sebanyak $100 \mathrm{~mL}$ dikontakkan dengan 0,1 gram arang aktif dengan berbagai variasi waktu pengocokkan yaitu 2, 10, 30, 60, 90 dan 120 menit dengan ukuran partikel arang aktif 100 mesh. Larutan kemudian dianalisis nilai BOD, COD dan TSS. 


\section{Penentuan pH optimum}

Air limbah industri tapioka diambil sebanyak $100 \mathrm{~mL}$ dikontakkan dengan 0,1 gram arang aktif pada waktu kontak optimum dan diujikan dengan variasi $\mathrm{pH} \mathrm{4,} \mathrm{5,} \mathrm{6,} \mathrm{7,} \mathrm{8,} 9$ dan 10 menggunakan $\mathrm{HCl}$ dan $\mathrm{NaOH}$. Larutan kemudian dianalisis nilai BOD, COD dan TSS.

Penentuan nilai BOD, COD dan TSS dalam air limbah industri tapioka pada berbagai variasi waktu kontak dan pH optimum setelah diolah (treatment) dengan arang aktif

a. Masing-masing parameter dianalisis sesuai dengan metode analisis.

b. Pengukuran dilakukan secara duplo. Penentuan persentase penurunan kadar masing-masing parameter.
$\%$ penurunan $=\frac{(C o-C 1)}{C o} \times 100 \%$

dimana :

$\mathrm{Co}=$ konsentrasi awal parameter

$\mathrm{C} 1=$ konsentrasi akhir parameter

\section{HASIL DAN PEMBAHASAN \\ Karakterisasi Arang Aktif}

Karakterisasi arang aktif

dimaksudkan untuk mengetahui kondisi sebenarnya dari arang aktif sehingga diharapkan arang aktif dari ampas kopi mampu berfungsi dengan baik. Karakterisasi arang aktif dapat diperlihatkan melalui beberapa pengujian mutu arang aktif meliputi penentuan rendemen, kadar air, kadar abu dan daya serap terhadap iodium. Besarnya nilai karakterisasi arang aktif amaps kopi dapat diperlihatkan pada Tabel 1 .

Tabel 1. Karakterisasi arang aktif

\begin{tabular}{lcc}
\hline \multicolumn{1}{c}{ Parameter } & $\begin{array}{c}\text { Hasil Analisis Arang } \\
\text { Aktif }\end{array}$ & $\begin{array}{c}\text { Standar Mutu Arang Aktif } \\
\text { SNI No. 06-3730-1995 }\end{array}$ \\
\hline Rendemen & $14,55 \%$ & - \\
Kadar Air & $3,4 \%$ & Maksimum 15\% \\
Kadar Abu & $1,88 \%$ & Maksimum 10\% \\
Daya Serap Terhadap & $750,25 \mathrm{mg} / \mathrm{g}$ & Minimum $750 \mathrm{mg} / \mathrm{g}$ \\
Iodium & & \\
\hline
\end{tabular}

Besarnya rendemen arang aktif menunjukkan jumlah arang aktif yang dihasilkan setelah melalui proses aktivasi dan karbonisasi. Rendemen arang aktif yang dihasilkan relatif kecil, yaitu sebesar $14,55 \%$. Rendemen arang aktif yang rendah dapat disebabkan oleh jumlah udara saat karbonisasi, ukuran bahan baku dan suhu akhir karbonisasi. Ukuran bahan yang terlalu kecil memungkinkan kehilangan arang dalam jumlah yang relatif banyak karena banyak dihasilkan abu, sedangkan ukuran bahan yang terlalu besar menyebabkan kurang meratanya pengarangan sehingga tidak semua bahan dapat terkarbonisasi secara sempurna. Suhu akhir karbonisasi mempengaruhi jumlah rendemen yang kecil karena dihasilkan tar dalam jumlah yang banyak.

Penetapan kadar air bertujuan untuk mengetahui sifat higroskopis arang aktif. Kadar air hasil penelitian relatif kecil, yaitu sebesar 3,4\%, kadar air ini telah memenuhi standar kualitas arang aktif berdasarkan SNI No. 06-3730-1995 yaitu maksimum $15 \%$ untuk arang aktif berbentuk serbuk. Kadar air yang diperoleh menunjukkan bahwa kandungan air terikat bahan baku yang dikarbonisasi lebih dahulu keluar sebelum diaktivasi. Kadar air yang rendah akan meningkatkan mutu arang karena meningkatkan daya serap terhadap gas atau cairan karena dengan semakin kecil molekul air dalam arang aktif, 
halangan molekul lain untuk masuk akan semakin kecil.

Penentuan kadar abu arang aktif dilakukan untuk mengetahui kandungan oksida logam atau kandungan bahan anorganik dalam arang aktif. Kadar abu pada penelitian ini adalah sebesar 2,5\%. Hasil ini telah memenuhi standar baku kualitas arang aktif berdasarkan SNI No. 06-3730-1995 yaitu maksimum 10\%. Data ini menunjukkan kandungan bahan anorganik yang terdapat dalam bahan terdapat dalam jumlah yang rendah.

Karakterisisasi lain dari arang aktif adalah daya serap arang aktif terhadap larutan iodium. Uji iodium menurut Cherimisinoff (1978), merupakan parameter untuk mengetahui kemampuan arang aktif dalam menyerap molekul-molekul dengan berat molekul kecil dan zat dalam fasa cair. Daya serap iodium yang diperoleh adalah sebesar $750,25 \mathrm{mg} / \mathrm{g}$. Data ini menunjukkan bahwa arang aktif telah memenuhi standar baku kualitas arang aktif berdasarkan SNI No. 06-3730-1995 yaitu minimum $750 \mathrm{mg} / \mathrm{g}$. Besarnya daya serap arang aktif terhadap iodium disebabkan karena senyawa hidrokarbon yang tertinggal pada permukaan arang terbuang pada saat proses aktivasi sehingga permukaan arang menjadi aktif. Berdasarkan banyaknya rendemen, kadar air, kadar abu dan daya serap terhadap iodium, menunjukkan arang aktif yang dihasilkan pada penelitian ini cukup baik digunakan sebagai adsorben dalam penurunan nilai BOD, COD dan TSS limbah cair industri tapioka.

\section{Penentuan Waktu Kontak Optimum Arang Aktif dari Ampas Kopi Terhadap Penurunan Nilai BOD, COD dan TSS Limbah Cair Industri Tapioka}

Variasi waktu kontak dilakukan untuk mengetahui pengaruh pengocokan pada berbagai variasi waktu kontak terhadap proses adsorpsi arang aktif dalam menurunkan nilai BOD, COD dan TSS limbah cair industri tapioka. Pengocokan itu sendiri berfungsi untuk memberi kesempatan pada partikel karbon arang aktif dan limbah untuk bersinggungan dengan adsorbat yang akan diserap.

Ukuran partikel arang aktif yang digunakan dalam proses adsorpsi dapat mempengaruhi waktu kontak optimum yang dicapai. Penelitian ini menggunakan ukuran partikel 100 mesh karena semakin kecil ukuran partikel arang aktif maka semakin besar luas permukaan arang aktif yang tersedia untuk mengadsorpsi limbah cair industri tapioka sehingga proses adsorpsi lebih cepat terjadi.

Tabel 2. Persentase adsorpsi arang aktif ampas kopi pada variasi ukuran partikel

\begin{tabular}{cc}
\hline Ukuran partikel (mesh) & Persentase adsorpsi (\%) \\
\hline 100 & 99,4 \\
40 & 92,8 \\
30 & 61,2 \\
\hline
\end{tabular}

Sumber : Lubis dan Nasution (2002)

Adsorpsi limbah oleh arang aktif dari ampas kopi dengan ukuran partikel 100 mesh pada variasi waktu kontak $2,10,30,60,90,120$ menit mencapai waktu kontak optimum pada waktu kontak 30 menit seperti ditunjukkan pada Gambar 1. 


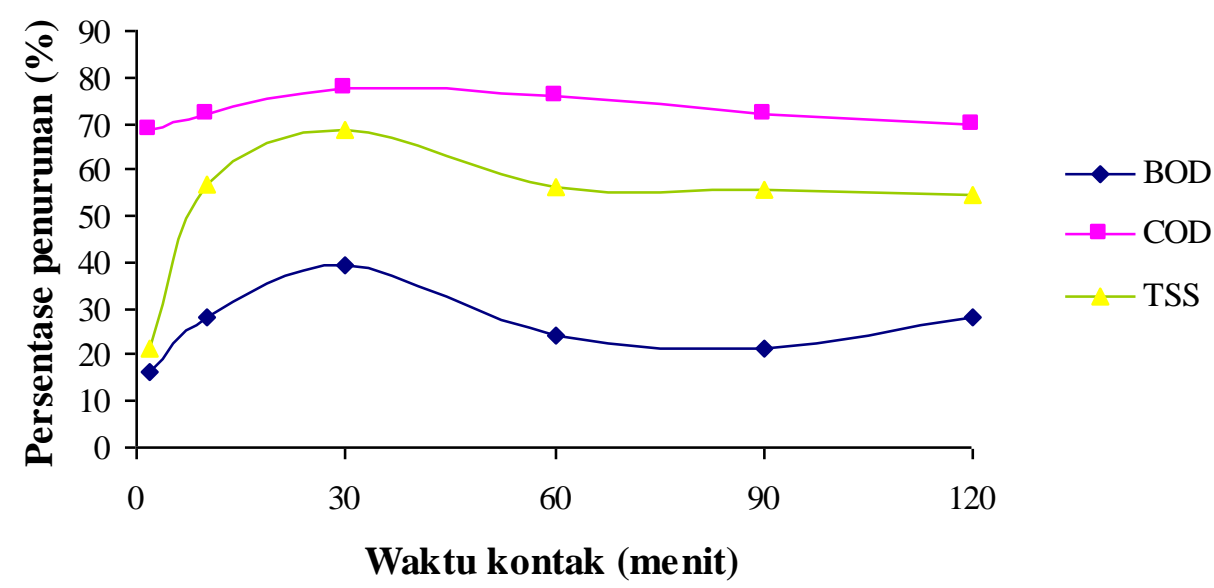

Gambar 1. Kurva persentase penurunan nilai BOD, COD dan TSS limbah cair industri tapioka pada berbagai variasi waktu kontak

Gambar 1. menunjukkan bahwa arang aktif dari ampas kopi dapat digunakan untuk mengadsorpsi BOD, COD dan TSS limbah cair industri tapioka. Pada menit ke-2 sampai menit ke-30 terjadi peningkatan persentase penurunan BOD, COD dan TSS limbah cair industri tapioka karena arang yang sudah diaktifkan permukaannya menjadi lebih luas karena telah bebas dari deposit hidrokarbon dan pori-porinya telah terbuka sehingga mampu mengadsorpsi limbah cair industri tapioka (Lubis dan Nasution, 2002). Proses adsorpsi akan terus berlangsung hingga dicapai waktu kontak optimum, dimana terjadi penyerapan limbah paling besar oleh arang aktif, yaitu pada waktu kontak 30 menit. Pada saat waktu kontak optimum tercapai, semua permukaan arang aktif telah tertutup oleh adsorbat berupa limbah cair industri tapioka. Hal ini sesuai dengan teori adsorpsi Langmuir yang menyatakan bahwa kecepatan adsorpsi pada permukaan berbanding lurus dengan bagian permukaan adsorben atau sisi aktif yang tidak diisi oleh molekul yang teradsorpsi.

Persentase penurunan BOD, COD dan TSS limbah cair industri tapioka mengalami penurunan setelah diperoleh waktu kontak optimum yaitu pada menit ke-30 sampai menit ke-90 dikarenakan arang aktif telah jenuh oleh molekul teradsorpsi sehingga apabila waktu pengocokan arang aktif terhadap limbah cair industri tapioka diperpanjang walaupun dengan tekanan yang diperbesar tidak akan meningkatkan jumlah molekul yang teradsorpsi namun arang aktif yang telah menyerap limbah secara optimal akan melepas kembali adsorbatnya ke larutan blanko atau limbah. Hal ini karena permukaan adsorben yang telah diisi oleh molekul teradsorpsi telah tertutup sempurna sehingga apabila waktu kontaknya diperpanjang, sudah tidak ada permukaan adsorben yang bebas sehingga molekul adsorbat akan lepas kembali ke larutan blanko. Pada saat demikian dicapai waktu kontak setimbang antara arang aktif sebagai adsorben dan limbah sebagai adsorbatnya. Pada proses adsorpsi arang aktif dari ampas kopi dengan adsorbat limbah cair industri tapioka terjadi proses adsorpsi fisik, dimana terdapat gaya tarik-menarik antara adsorben arang aktif dari ampas kopi dan adsorbat berupa limbah cair, sehingga adsorbat dapat dengan bebas menutupi keseluruhan permukaan padatan. 
Penentuan pH Optimum Arang Aktif dari Ampas Kopi Terhadap Penurunan Nilai BOD, COD dan TSS Limbah Cair Industri Tapioka Pada Waktu Kontak Optimum

Penentuan $\mathrm{pH}$ optimum dilakukan pada berbagai variasi $\mathrm{pH}$ limbah cair industri tapioka yaitu $\mathrm{pH} \mathrm{4,} \mathrm{5,} \mathrm{6,} \mathrm{7,} \mathrm{8,} 9$ dan 10 dengan menggunakan waktu kontak optimum 30 menit. Pengaturan $\mathrm{pH}$ dilakukan dengan cara penambahan $\mathrm{HCl} 0,1 \mathrm{~N}$ dan $\mathrm{NaOH} 0,1 \mathrm{~N}$. pH awal limbah cair industri tapioka sebelum diolah dengan menggunakan arang aktif adalah berkisar pada $\mathrm{pH}$ asam 3,5 - 4,0.

\section{Biochemical Oxygen Demand (BOD)}

Biochemical Oxygen Demand
(BOD) didefinisikan sebagai banyaknya oksigen yang diperlukan oleh organisme pada saat pemecahan bahan organik pada kondisi aerobik, dimana organisme hidup bertindak sebagai medium untuk menguraikan bahan organik menjadi $\mathrm{CO}_{2}$ dan $\mathrm{H}_{2} \mathrm{O}$. Pengukuran $\mathrm{BOD}$ pada penelitian ini adalah dengan menggunakan metode titrasi Winkler yang didasarkan pada oksigen dalam sampel yang akan mengoksidasi $\mathrm{MnSO}_{4}$ menjadi endapan $\mathrm{MnO}_{2}$, dengan adanya penambahan $\mathrm{H}_{2} \mathrm{SO}_{4}$ dan $\mathrm{KI}$ akan dibebaskan iodin yang ekuivalen dengan jumlah oksigen terlarut (Alaerts dan Santika, 1991). Reaksi yang terjadi adalah sebagai berikut :

$$
\begin{aligned}
& \mathrm{MnSO}_{4}+2 \mathrm{KOH} \rightarrow \mathrm{Mn}(\mathrm{OH})_{2}+\mathrm{K}_{2} \mathrm{SO}_{4} \\
& \mathrm{Mn}(\mathrm{OH})_{2}+\frac{1}{2} O_{2} \rightarrow \mathrm{MnO}_{2}+\mathrm{H}_{2} \mathrm{O} \\
& \mathrm{MnO}_{2}+2 \mathrm{KI}+2 \mathrm{H}_{2} \mathrm{O} \underset{\text { pHrendah }}{\longrightarrow} \mathrm{Mn}(\mathrm{OH})_{2}+\mathrm{I}_{2}+2 \mathrm{KOH} \\
& \mathrm{I}_{2}+2 \mathrm{~S}_{2} O_{3}^{2-} \rightarrow \mathrm{S}_{4} O_{6}^{2-}+2 \mathrm{I}^{-}
\end{aligned}
$$

Besarnya nilai BOD dihitung dari selisih kadar oksigen sebelum dan sesudah inkubasi selama 5 hari pada suhu $20^{\circ} \mathrm{C}$, karena persentase reaksi dari total reaksi BOD mencapai $75 \%$ dari total reaksi pada waktu inkubasi 5 hari. Pengukuran BOD dapat dipergunakan untuk menaksir beban pencemaran zat organik. Penentuan waktu inkubasi selama 5 hari dapat mengurangi kemungkinan adanya gangguan dari hasil oksidasi ammonia $\left(\mathrm{NH}_{3}\right)$ yang cukup tinggi yang dapat mengganggu dalam pengukuran BOD. Besarnya penurunan BOD limbah cair industri tapioka dengan adsorben arang aktif ampas kopi terhadap berbagai variasi $\mathrm{pH}$ pada waktu kontak optimum 30 menit dapat dilihat pada Gambar 2. 


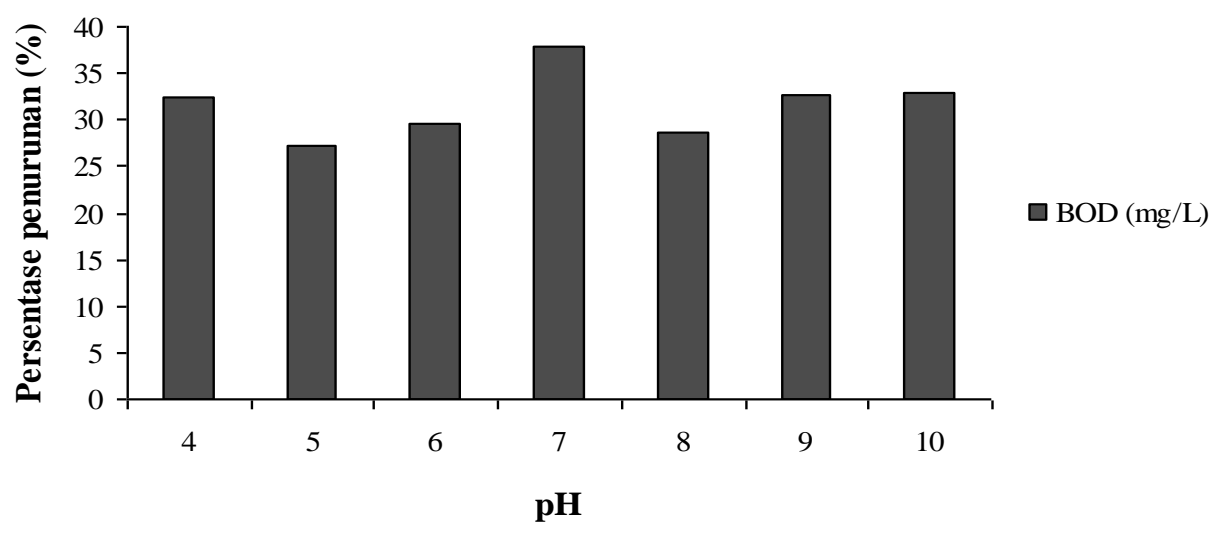

Gambar 2. Kurva persentase penurunan nilai BOD limbah cair industri tapioka pada berbagai variasi $\mathrm{pH}$ pada waktu kontak optimum.

Gambar 2 menunjukkan bahwa setelah mengalami pengolahan dengan menggunakan adsorben arang aktif dari ampas kopi, nilai BOD limbah cair industri tapioka mengalami penurunan sebesar $27-37 \%$ dari limbah awal. Pada pengolahan menggunakan $\mathrm{pH}$ asam, persentase penurunan nilai BOD cenderung lebih rendah daripada pada $\mathrm{pH}$ netral, proses adsorpsi limbah oleh arang aktif yang terjadi juga berkurang. Hal ini disebabkan karena pengolahan limbah pada keadaan asam menyebabkan kepekatan oksigen terlarut rendah karena oksigen digunakan untuk oksidasi bahanbahan organik dalam limbah cair industri tapioka, sedangkan kepekatan BOD-nya tinggi, yang menunjukkan bahan-bahan organik dalam air limbah terdapat dalam jumlah yang banyak.

Persentase penurunan nilai BOD terbesar diperoleh pada pengolahan dengan menggunakan $\mathrm{pH} 7$ yaitu sebesar $37,92 \%$. Hal ini disebabkan karena pada pengolahan menggunakan $\mathrm{pH} 7$ terjadi adsorpsi limbah oleh arang aktif secara maksimal yang dibantu oleh mikroorganisme dalam mendekomposisi bahan organik limbah sehingga nilai BOD akan berkurang. Pengolahan limbah menggunakan $\mathrm{pH}$ netral memungkinkan kehidupan biologis dalam limbah berjalan dengan baik sehingga senyawa organik dapat terdegradasi secara biologis dengan nilai BOD rendah. Nilai BOD yang rendah menunjukkan jumlah bahan organik dalam limbah terdapat dalam jumlah yang kecil dan kebutuhan oksigen untuk menguraikan bahan organik semakin kecil pula.

Persentase penurunan nilai BOD pada pengolahan menggunakan $\mathrm{pH}$ basa menunjukkan peningkatan kembali, dimana proses adsorpsi limbah oleh arang aktif lebih rendah daripada proses adsorpsi pada pemgolahan pada $\mathrm{pH}$ netral, hal ini disebabkan karena pada keadaan basa, radikal $\mathrm{OH}^{-}$yang terbentuk pada penambahan $\mathrm{NaOH}$ dapat memperbanyak senyawa organik yang dioksidasi sejalan dengan bertambahnya jumlah oksigen yang dibutuhkan untuk mendekomposisi senyawa organik. Hal ini menyebabkan nilai BOD akan mengalami kenaikkan.

\section{Chemical Oxygen Demand (COD)}

Prinsip pengukuran nilai COD adalah zat organik dalam limbah dioksidasi oleh pengoksidasi $\mathrm{KMnO}_{4}$ dalam keadaan asam yang mendidih. Sisa $\mathrm{KMnO}_{4}$ dalam larutan kemudian digunakan untuk menentukan jumlah oksigen yang terpakai dengan titrasi iodometri menggunakan tiosulfat dan indikator amilum.

Pengukuran COD juga melibatkan penambahan $\mathrm{HgSO}_{4}$ yang bertujuan 
untuk menghilangkan adanya gangguan dari ion klorida. Ion merkuri akan bergabung dengan ion klorida membentuk merkuri klorida. Sehingga dengan adanya ion $\mathrm{Hg}^{2+}$ ini, konsentrasi dari ion klorida menjadi sangat kecil dan tidak mengganggu oksidasi senyawa organik. Reaksi yang terjadi adalah sebagai berikut :

$$
\mathrm{Hg}^{2+}+2 \mathrm{Cl}^{-} \rightarrow \mathrm{HgCl}_{2}
$$

Pengukuran COD limbah cair industri tapioka pada berbagai variasi $\mathrm{pH}$ dengan waktu kontak optimum 30 menit dapat diperlihatkan pada Gambar 3.

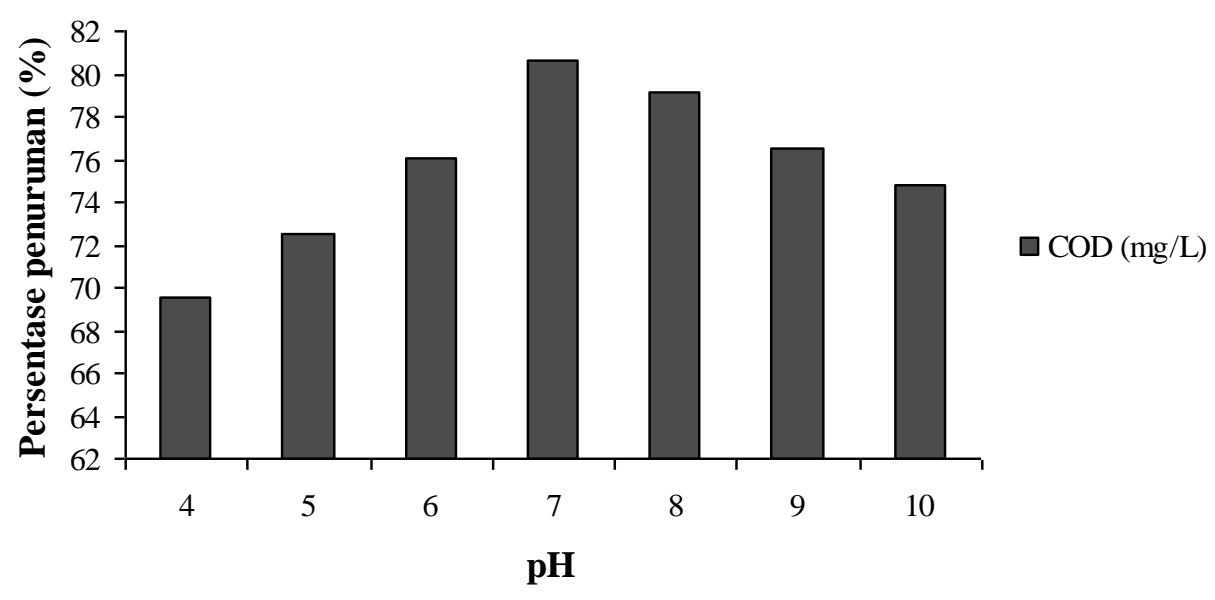

Gambar 3. Kurva persentase penurunan nilai COD limbah cair industri tapioka pada berbagai variasi $\mathrm{pH}$ pada waktu kontak optimum.

Data pada Gambar 3 menunjukkan bahwa pada pengolahan limbah cair industri tapioka dengan menggunakan $\mathrm{pH}$ asam dan basa mempunyai nilai COD yang masih tinggi dibandingkan pengolahan dengan menggunakan $\mathrm{pH}$ 7. Pada pengolahan dengan menggunakan $\mathrm{pH}$ asam, nilai COD mengalami kenaikan yang disebabkan karena proses adsorpsi limbah oleh arang aktif belum maksimal dan oksigen dalam air cukup untuk dapat mengoksidasi bahan organik dalam limbah. Serupa dengan pengukuran BOD, dengan tingginya kandungan bahan organik yang terdapat dalam limbah cair industri tapioka maka kebutuhan oksigen untuk mengoksidasi secara kimia juga semakin besar sehingga proses degradasi senyawa yang terdapat dalam limbah berjalan lamban.

Pengolahan limbah dengan $\mathrm{pH}$ netral menunjukkan proses adsorpsi limbah oleh arang aktif maksimal dan diperoleh persentase penurunan COD yang terbesar, yaitu sebesar $80,58 \%$. Pengolahan pada $\mathrm{pH}$ netral menunjukkan terjadi proses adsorpsi limbah oleh arang aktif secara maksimal. Proses adsorpsi ini dibantu dengan adanya oksidator kuat $\mathrm{KMnO}_{4}$ yang membantu mempercepat proses dekomposisi bahan organik dalam limbah sehingga dicapai penurunan nilai COD yang maksimal. Pada pengolahan limbah dengan menggunakan $\mathrm{pH}$ basa menunjukkan persentase penurunan COD yang rendah, sehingga proses adsorpsi pada $\mathrm{pH}$ basa berkurang dibandingkan pada $\mathrm{pH}$ netral, hal ini disebabkan karena dengan penambahan $\mathrm{NaOH}$ menyebabkan radikal $\mathrm{OH}^{*}$ yang terbentuk memperbanyak senyawa organik yang dioksidasikan sehingga jumlah oksigen yang dibutuhkan untuk mendekomposisi senyawa organik limbah dibutuhkan dalam jumlah yang besar. 
Total Suspended Solid (TSS)

Hasil pengukuran TSS pada berbagai variasi $\mathrm{pH}$ pada waktu kontak optimum menunjukkan persentase penurunan yang kecil pada pengolahan dengan $\mathrm{pH}$ asam maupun pada $\mathrm{pH}$ basa dibandingkan dengan pengolahan limbah pada pH 7, yaitu sebesar 63,54\%. Penurunan nilai TSS pada berbagai variasi $\mathrm{pH}$ pada waktu kontak optimum dapat ditunjukkan pada Gambar 4.

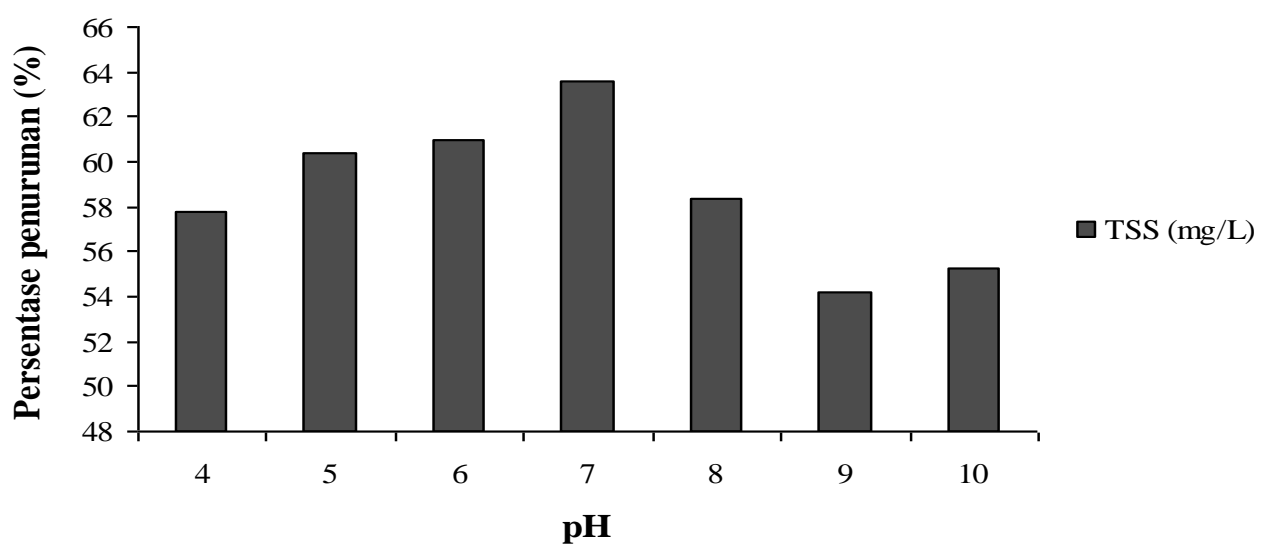

Gambar 4. Kurva persentase penurunan nilai TSS limbah cair industri tapioka pada berbagai variasi $\mathrm{pH}$ pada waktu kontak optimum.

Gambar 4 menunjukkan bahwa pengolahan TSS pada $\mathrm{pH}$ asam menghasilkan penurunan nilai TSS yang kecil karena proses adsorpsi yang berlangsung belum maksimal, karena pengolahan pada $\mathrm{pH}$ asam dapat mendegradasi senyawa-senyawa organik yang akan menyebabkan zat tersuspensi menjadi terlarut. Hal ini akan berlangsung sampai dicapai $\mathrm{pH}$ optimum, dimana dicapai proses adsorpsi yang maksimal yaitu pada $\mathrm{pH} 7$ karena pada $\mathrm{pH}$ netral proses degradasi senyawa organik dan anorganik berlangsung secara optimum menyebabkan zat-zat tersuspensi terlarut kembali dalam jumlah yang banyak, yang akan dapat meningkatkan persentase penurunan nilai TSS. Namun apabila $\mathrm{pH}$ dinaikkan dengan penambahan basa $\mathrm{NaOH}$, proses adsorpsi arang aktif terhadap limbah akan berkurang sebagai akibat terbentuknya hidroksida-hidroksida yang sukar larut, sehingga TSS akan naik, dibuktikan dengan tingkat kekeruhan yang tinggi.
Secara keseluruhan, nilai BOD, COD dan TSS limbah cair industri tapioka dapat diturunkan dengan metode adsorpsi arang aktif dengan waktu kontak optimum 30 menit dan pada $\mathrm{pH}$ optimum 7. Persentase penurunan nilai BOD, COD dan TSS ditujukan untuk melihat seberapa besar kekuatan adsorpsi arang aktif dari ampas kopi dalam menurunkan nilai BOD, COD dan TSS limbah cair industri tapioka pada waktu kontak optimum dan pada $\mathrm{pH}$ optimum. Persentase penurunan BOD, COD dan TSS limbah cair industri tapioka setelah dilakukan pengolahan limbah pada waktu kontak optimum 30 menit dan $\mathrm{pH}$ optimum 7, secara berturut-turut nilainya adalah sebesar 33,51\%; 78,96\%; 61,05\%. Dilihat dari persentase penurunan ketiga parameter tersebut, metode arang aktif dari ampas kopi ini cukup efektif dalam menurunkan parameter pencemaran air. 


\section{KESIMPULAN}

Berdasarkan penelitian yang telah dilakukan dapat diambil kesimpulan sebagai berikut :

1. Kualitas arang aktif dari ampas kopi yang diperoleh meliputi rendemen sebesar 14,55\%; kadar air sebesar 3,4\%; kadar abu sebesar 1,88\% dan daya serap terhadap iodium sebesar $750,25 \mathrm{mg} / \mathrm{g}$.

2. Waktu kontak optimum dan $\mathrm{pH}$ optimum arang aktif dari ampas kopi dalam penurunan nilai BOD, COD dan TSS limbah cair industri tapioka adalah pada waktu kontak 30 menit dan $\mathrm{pH} 7$.

3. Persentase penurunan nilai BOD, COD dan TSS limbah cair industri tapioka dengan menggunakan arang aktif dari ampas kopi pada waktu kontak optimum dan $\mathrm{pH}$ optimum, adalah BOD sebesar 33,51\%; COD sebesar 78,96\% dan TSS sebesar $61,05 \%$.

\section{DAFTAR PUSTAKA}

Alaerts, G. dan S. S. Santika, 1991, Metoda Penelitian Air, Usaha Nasional, Surabaya.

Cheremisinoff dan A. C. Morresi, 1978, Carbon Adsorption Applications, Carbon Adsorption Handbook, Ann Arbor Science Publishers, Inc., Michigan.

Direktorat Jenderal Industri Kecil dan Menengah, 2007, Pengelolaan Limbah Industri Pangan, Departemen Perindustrian, Jakarta.

Hidayat, S. A, 2007, Penurunan Nilai TSS, BOD dan COD Limbah Cair Industri Tahu Menggunakan Sistem Zeolit Teraktivasi dan Terimpregnasi $\mathrm{TiO}_{2}$, Skripsi, Universitas Jenderal Soedirman.
Purwokerto

(Tidak

Dipublikasikan).

Jenie, B. S. L. dan W. P. Rahayu, 1993, Penanganan Limbah Industri Pangan, Penerbit Kanisius, Yogyakarta.

Lubis, S. dan R. Nasution, 2002, Pemanfatan Limbah Bubuk Kopi Sebagai Adsorben Pada Penurunan Kadar Besi (Fe Anorganik) Dalam Air Minum, Jurnal Natural Vol.2, No.2.

Nurhasan dan B. Pramudyanto, 1991, Penanganan Air Limbah Pabrik Tahu, Yayasan Bina Karya Lestari, Jakarta.

Sembiring, M. T. dan T. S. Sinaga, 2003, Arang Aktif (Pengenalan dan Proses Pembuatannya), USU Press, Sumatera Utara.

Setiadi, T, 2007, Pengelolaan Limbah Industri, http://www.majarikanayakan.co $\mathrm{m} / \quad 2008 / 01 /$ teknologipengolahan-air-limbah/,

Diakses pada tanggal 4 Januari 2008.

SII, 1989, Syarat Mutu Arang Aktif, Departemen Perindustrian RI, Jakarta.

Sulistiono, S. Santoso, T. Sudibyaningsih, E. Riwidiharto dan Soeharyanto, 1989, Uji Biologi Air Limbah Industri Tapioka terhadap Ikan Tawes (Puntius javanicus Blkr), Laporan Penelitian, Fakultas Biologi Universitas Jenderal Soedirman, Purwokerto (Tidak Dipublikasikan). 